\title{
Optimization of Parameters for Biogas Production from Bagasse Using Taguchi Method
}

\author{
Budiyono Budiyono ${ }^{1}$, Aldi Budi Riyanta ${ }^{1}$, Siswo Sumardiono ${ }^{1}$, \\ Bakti Jos $^{1}$, Iqbal Syaichurrozi ${ }^{2 *}$ \\ ${ }^{1}$ Department of Chemical Engineering, Faculty of Engineering, University of Diponegoro, Semarang 50239, Indonesia \\ ${ }^{2}$ Department of Chemical Engineering, Faculty of Engineering, University of Sultan Ageng Tirtayasa, \\ Jl. Jendral Soedirman Km 3, Cilegon 42435, Indonesia
}

Received: 3 August 2020

Accepted: 2 February 2021

\begin{abstract}
Biogas production from lignocellulosic compounds is affected by several parameters. In the present article, Taguchi method was applied in evaluating the parameters including inoculums type (cow rumen and cow dung), pretreatment time $(0,24,48 \mathrm{~h})$, and total solid content $(2,5,10 \%)$. The $\mathrm{L}_{18}\left(2^{1} \times 3^{2}\right)$ full factorial design with a mixed orthogonal array was selected to conduct the experiments. Furthermore, to find the percentage contribution of each parameter on biogas yield, the analysis of variance was applied. The analysis results showed that the best inoculum type was cow rumen (signal-to-noise 27.59), the best pretreatment time was $48 \mathrm{~h}$ (signal-to-noise 28.20) and the best total solid was $2 \%$ (signal-to-noise 31.98). Furthermore, the percentage contribution of inoculum type, pretreatment time, and total solid was $0.43,7.97$ and $83.51 \%$ respectively. It means the total solid was the most effective parameter and then it was followed by pretreatment and inoculums. The predicted maximum biogas yield of $42.59 \mathrm{~L} / \mathrm{kg}$ resulted from an optimum condition of inoculum of cow rumen, pretreatment time of $48 \mathrm{~h}$, and a total solid of $2 \%$. In the confirmation test, the Taguchi method could predict biogas yield successfully with $\mathrm{R}^{2}$ of 0.919 .
\end{abstract}

Keywords: bagasse, biogas, inoculum, Taguchi method, total solid

\section{Introduction}

Because of limitation of non-renewable energy source accessibility, Indonesia will reduce their need and increase renewable energy production. Based on data from Dewan Energy Nasional [1], around 92\% of total national energy consumption in 2013 was reinforced by fossil fuels and the remaining $8 \%$ by

*e-mail: iqbal_syaichurrozi@untirta.ac.id iqbalsyaichurrozi@gmail.com renewable energy. The government is focusing to cut down the level of fossil fuel consumption to be $69 \%$ by supplanting it with sustainable power sources in year 2050 [1]. Therefore, renewable energy is becoming one of the major topics in Indonesia. Furthermore, the conversion of wastes to renewable energy is a very thought-provoking idea [2-4]. Biogas is a renewable energy that could be potentially applied as alternative energy in Indonesia. Compared with other renewable energy sources, biogas has some superiorities: 1) it is easy to be produced; 2) it can be produced from wastes; 3) it can be utilized directly in gas form or converted 
to be other energy forms; 4) bottom product of biogas reactors can be used as biofertilizer; and 5) it is suitable to be produced at mesophilic temperatures in Indonesia [2, 5-7]. As an agricultural country, Indonesia is rich in agricultural wastes; one of them is bagasse. Bagasse, one of lignocellulosic wastes, is produced from sugarcane milling process in sugar factory [8]. Bagasse contains high cellulose, so it is very potential to be processed to biogas [9].

In anaerobic digestion (AD), there are some parameters that affect the biogas yield, i.e. inoculums type [10], chemical pretreatment [11] and total solids [6]. Previously some authors have reported about biogas production from bagasse. However, in all cases, every one of them simply considered the job of one parameter in a single time on biogas yield from bagasse [1214]. In reality, some parameters are affecting the AD performance simultaneously [7]. Hence, optimization of the parameters for producing biogas from bagasse is necessary to do.

To optimize the parameters, there are many optimizing methods such as Genetic Algorithm (GA), Artificial Neural Network (ANN), Response Surface Method (RSM) and Taguchi method [15]. In present article, the Taguchi method was applied to study the different experimental parameters with the minimum number of trials as it exhibits an orthogonal array [16]. Besides this, It will provide the influence of each aspect and introduce the most effective and the optimum conditions on biogas yield [7, 15-16]. Therefore, this study has a goal to investigate the effect of several parameters on biogas yield from bagasse i.e. inoculums type (cow dung and cow manure), pretreatment time $(0,24,48 \mathrm{~h})$ and total solid content $(2,5,10 \%)$ then optimization of these parameters through the Taguchi method. Syaichurrozi et al. [17] suggested that the chemical pretreatment for organic solid prior AD should be conducted for $48 \mathrm{~h}$. Above that time, it was not effective. Therefore, this study set the low, middle and high level for pretreatment time on 0,24 and $48 \mathrm{~h}$. Furthermore, the optimum total solid content for agricultural wastes, municipal solid waste and banana stem waste was 9\% [18], 10\% [19] and 2-4\% [20]. It means that the optimum range of total solid for solid waste is $2-10 \%$. Based on that, this study set the low, middle and high level for total solid on 2,5 and $10 \%$. This idea was new and original as no previous author was conducting the Taguchi technique to evaluate the effect of parameters on biogas from bagasse. The anaerobic digestion was run during $84 \mathrm{~d}$ using anaerobic batch digesters.

\section{Materials and Methods}

\section{Materials}

The raw bagasse was obtained from sugar factories in Jatibarang, Brebes, Central Java Province (which was also utilized by Sumardiono et al. [14]) and dried under the sun for seven days. After drying, it was milled and sieved to obtain 22 mesh [14]. Then the raw bagasse was pretreated by soaking it in a solution of $\mathrm{NaOH} 2 \% \mathrm{v} / \mathrm{v}$ during 24 and $48 \mathrm{~h}$. The inoculums (rumen fluid and dung of cow) were obtained from cow slaughterhouses located in Jatibarang, Brebes, Central Java Province. The total solid (TS) and volatile solid (VS) in the above mentioned materials could be seen in Table 1 .

\section{Experimental Setup}

A laboratory batch of anaerobic digester (made form polyethylene) of volume $5 \mathrm{~L}$ was used in this experiment (adapted from [21]). The digester was plugged with rubber and a valve was used to determine biogas volume $[2,6]$.

\section{Experimental Design and Procedures}

The bagasse was mixed with water to make a slurry with total solid (TS) of 2, 5, 10\% and a total volume of 2 L. The obtained slurry was fed to digesters and inoculums (about $20 \%$ of the total slurry) were added in it. To maintain the substrate $\mathrm{pH}$ during fermentation, the buffer $\left(\mathrm{NaHCO}_{3}\right)$ was added. Fermentation was done for $84 \mathrm{~d}$ at the condition of mesophilic temperature $\left(28-30^{\circ} \mathrm{C}\right)$ and pressure of 1 atm. Biogas volume was measured every day by using the water displacement method. The digester was connected to the biogas collector (made from a

Table 1. TS and VS content in material and inoculums [14].

\begin{tabular}{|c|c|c|c|}
\hline \multirow{2}{*}{ Biomass } & \multicolumn{2}{|c|}{ Characteristics } \\
\cline { 2 - 4 } & TS \% & VS \% & 0.99 \\
\hline Raw bagasse & 79.64 & 78.83 & 0.97 \\
\hline Bagasse after pretreatment 24 h & 79.07 & 77.00 & 0.98 \\
\hline Bagasse after pretreatment 48 h & 78.50 & 76.83 & 0.54 \\
\hline Cow rumen & 26.50 & 14.33 & 0.79 \\
\hline Cow dung & 16.67 & 13.17 & \\
\hline
\end{tabular}




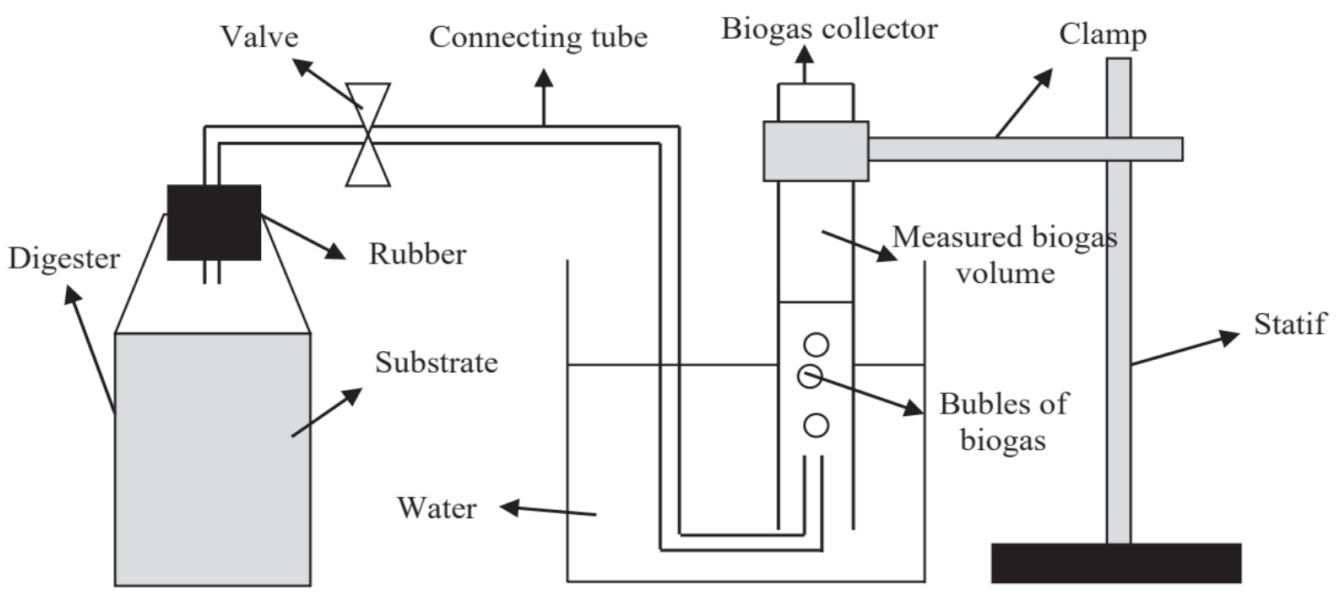

Fig. 1. The schematic diagram of the experiment.

reversed cylindrical glass) using a plastic tube. The biogas collector was immersed in water. Furthermore, the valve was used to close-open the plastic tube for measuring biogas volume. When the valve was opened, the biogas flew through the tubes and it was stored and replaced the amount of water in the gas collector [17]. Furthermore, the total biogas volume was the sum of daily biogas volumes from 0 until $84 \mathrm{~d}$ of fermentation. The schematic diagram of this experiment is shown in Fig. 1.

\section{Taguchi Method}

The Taguchi method uses orthogonal arrays to reduce the number of experiments and limits the effects of parameters. It gives a simple, proficient, and methodical approach to indicate the optimum parameters for biogas production [22-24]. A loss function is used by the strategy to compute the deviation between the experimental and targeted values. Furthermore, the loss function is expressed in value of signal-to-noise $(\mathrm{S} / \mathrm{N})$ ratio [25]. The $\mathrm{S} / \mathrm{N}$ ratio has three quality characteristics which are: the smaller-the-better, the larger-the-better and the nominal-the-best [15]. In case of maximizing the biogas yield, the larger-thebetter characteristic was applied using Eq. 1 [26].

$$
S / N=-10 \log \left[\frac{1}{n} \sum_{i=1}^{n} \frac{1}{y_{i}^{2}}\right]
$$

...where, $\mathrm{S} / \mathrm{N}$ is signal-to-noise ratio, $y_{i}$ is the signal (biogas yield) measured in each experiment and $n$ is the number of observations of the experiment.
Inoculums type, chemical pretreatment time and total solid were proposed parameters and then the levels from each parameter were presented in Table 2 . Based on Table 2, the orthogonal array $\mathrm{L}_{18}\left(2^{1} \times 3^{2}\right)$ was the most suitable to be applied in way to determine the optimal combination parameters and to investigate the influence of each parameter on biogas yield. Therefore, experiments were conducted based on the matrix of the orthogonal array $\mathrm{L}_{18}$ presented in Table 3 .

\section{Results and Discussion}

\section{Analysis of the Signal-to-Noise (S/N) Ratio}

Total biogas volume $(V b)$ was measured through experimental design for each combination of the parameters by using the Taguchi method. The optimization of the parameters was provided by signal-to-noise $(\mathrm{S} / \mathrm{N})$ ratios. The most elevated estimation of biogas yield was the primary concern, therefore larger-the-better characteristic was applied to calculate the $\mathrm{S} / \mathrm{N}$ ratio. The $\mathrm{S} / \mathrm{N}$ ratio values for observations of the biogas yield are shown in Table 4. Furthermore, from Table 4, the average value of $\mathrm{Vb}$ and $\mathrm{S} / \mathrm{N}$ ratio were calculated to be $26.35 \mathrm{~L} / \mathrm{kg}$ and 27.4704 respectively. Analysis of the influence of each parameter (inoculums, pretreatment, total solid) on biogas yield was performed with an "S/N response table" for $V b$ which is shown in Table 5, and then graphically it is appeared in Fig. 2. The optimal parameter combination for maximizing the biogas yield

Table 2. Biogas production parameters and their levels.

\begin{tabular}{|c|c|c|c|c|}
\hline Parameters & Symbol & Level 1 & Level 2 & Level 3 \\
\hline Inoculums & A & CR & CD & - \\
\hline Pretreatment time (hours) & B & 0 & 24 & 48 \\
\hline Total solid (\%) & C & 2 & 5 & 10 \\
\hline
\end{tabular}


Table 3. Full factorial design with orthogonal array of Taguchi $\mathrm{L}_{18}\left(2^{1} \times 3^{2}\right)$.

\begin{tabular}{|c|c|c|c|}
\hline $\begin{array}{c}\text { Experiment } \\
\text { No. }\end{array}$ & Parameter A & Parameter B & Parameter C \\
\hline 1 & 1 & 1 & 1 \\
\hline 2 & 1 & 1 & 2 \\
\hline 3 & 1 & 1 & 3 \\
\hline 4 & 1 & 2 & 1 \\
\hline 5 & 1 & 2 & 2 \\
\hline 6 & 1 & 2 & 3 \\
\hline 7 & 1 & 3 & 1 \\
\hline 8 & 1 & 3 & 2 \\
\hline 9 & 1 & 3 & 3 \\
\hline 10 & 2 & 1 & 1 \\
\hline 11 & 2 & 1 & 2 \\
\hline 12 & 2 & 1 & 3 \\
\hline 13 & 2 & 2 & 1 \\
\hline 14 & 2 & 2 & 2 \\
\hline 15 & 2 & 2 & 3 \\
\hline 16 & 2 & 3 & 1 \\
\hline 17 & 2 & 3 & 2 \\
\hline 18 & 2 & 3 & 3 \\
\hline
\end{tabular}

could be easily determined from Table 5 and Fig. 2. The best level for each parameter was that it had the highest $\mathrm{S} / \mathrm{N}$ ratio. The highest $\mathrm{S} / \mathrm{N}$ ratio value was shown by value in bold mode in Table 5. The levels and $\mathrm{S} / \mathrm{N}$ ratio for the parameters resulting in the best $V b$ value were specified as parameter A (Level $1, \mathrm{~S} / \mathrm{N}=27.59$ ), parameter $\mathrm{B}$ (Level 3, $\mathrm{S} / \mathrm{N}=28.20$ ), parameter $\mathrm{C}$ (Level 1, $\mathrm{S} / \mathrm{N}=31.98$ ). That implies a maximum $\mathrm{Vb}$ was obtained by optimizing condition of inoculums of cow rumen (A1), pretreatment during $48 \mathrm{~h}$ (B3), and total solid content of $2 \%(\mathrm{C} 1)$.

\section{Evaluation of Experimental Results}

According to Fig. 2 and Table 5, using cow rumen (CR) as inoculums could produce more total biogas volume as compared to using cow dung (CD). The $\mathrm{CD}$ contained higher total microorganisms than $\mathrm{CR}$ [27]. However, the number of ruminant bacteria in $\mathrm{CR}$ was higher than CD [28]. The substrate used in this investigation was bagasse which is cellulosic biomass. The presence of ruminant bacteria in CR could increase the biogas production rate, which results in high biogas yield. However, the type of inoculums (CR or CD) did not influence the biogas yield significantly. The $\mathrm{S} / \mathrm{N}$ value using $C R$ and $C D$ as inoculums is 27.59 and 27.35 respectively. Therefore, the factor of inoculums was not an effective parameter. Furthermore, the pretreatment also affected the biogas yield. The surface morphology of bagasse before and after pretreatment was analyzed using SEM (Fig. 3). After pretreatment using $\mathrm{NaOH}$ $2 \%$ during 24 and $48 \mathrm{~h}$, the surface morphology of pretreated bagasse was more open than raw bagasse [14]. It was in line with Kong et al. [29] and Montgomery and Bochmann [30], where pretreatment using alkali could swell the surface lignocellulosic biomass. Lignin and hemicellulose in fiber would dissolve, leaving a smooth surface of the fiber [31]. It showed that lignin and hemicelluloses in the surface

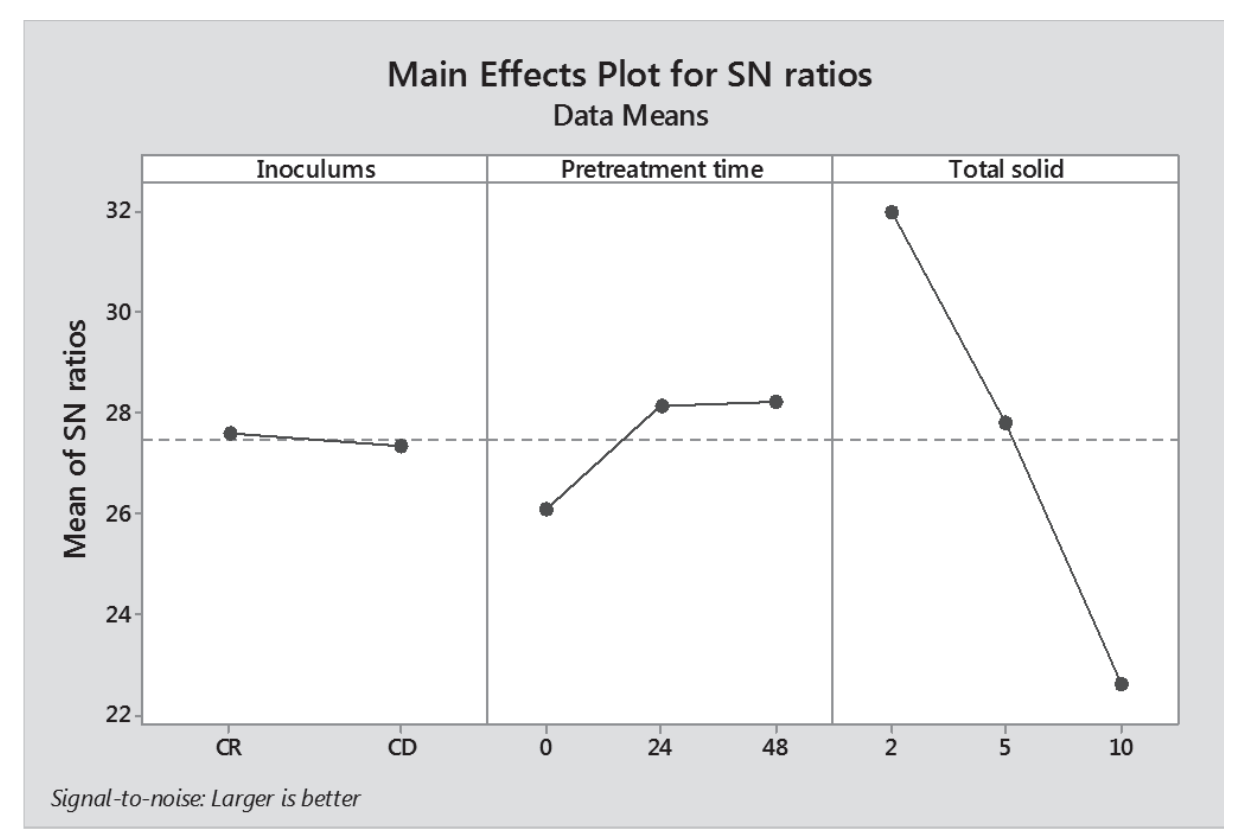

Fig. 2. Effect of parameters on average $\mathrm{S} / \mathrm{N}$ ratio for $V b$. 
Table 4. The results of experiments and $\mathrm{S} / \mathrm{N}$ ratio values.

\begin{tabular}{|c|c|c|c|c|c|}
\hline \multirow{2}{*}{ Experiment No. } & \multicolumn{3}{|c|}{ Parameter } & \multirow{2}{*}{ Biogas yield, $V b(\mathrm{~L} / \mathrm{kg})$} & \multirow{2}{*}{$\mathrm{S} / \mathrm{N}$ ratio for $\mathrm{Vb}$} \\
\hline & A Inoculums & B Pretreatment time (h) & C Total solid (\%) & & \\
\hline 1 & $\mathrm{CR}$ & 0 & 2 & $31.79^{*}$ & 30.0458 \\
\hline 2 & $\mathrm{CR}$ & 0 & 5 & $18.89^{*}$ & 25.5246 \\
\hline 3 & $\mathrm{CR}$ & 0 & 10 & $13.10^{*}$ & 22.3454 \\
\hline 4 & $\mathrm{CR}$ & 24 & 2 & $51.04^{*}$ & 34.1582 \\
\hline 5 & $\mathrm{CR}$ & 24 & 5 & 32.75 & 30.3042 \\
\hline 6 & $\mathrm{CR}$ & 24 & 10 & 9.96 & 19.9652 \\
\hline 7 & $\mathrm{CR}$ & 48 & 2 & $41.97^{*}$ & 32.4588 \\
\hline 8 & $\mathrm{CR}$ & 48 & 5 & 27.37 & 28.7455 \\
\hline 9 & $\mathrm{CR}$ & 48 & 10 & 17.27 & 24.7458 \\
\hline 10 & $\mathrm{CD}$ & 0 & 2 & 35.04 & 30.8913 \\
\hline 11 & $\mathrm{CD}$ & 0 & 5 & 17.74 & 24.9791 \\
\hline 12 & $\mathrm{CD}$ & 0 & 10 & 13.53 & 22.6260 \\
\hline 13 & $\mathrm{CD}$ & 24 & 2 & 39.33 & 31.8945 \\
\hline 14 & $\mathrm{CD}$ & 24 & 5 & 28.35 & 29.0511 \\
\hline 15 & $\mathrm{CD}$ & 24 & 10 & 14.89 & 23.4579 \\
\hline 16 & $\mathrm{CD}$ & 48 & 2 & 41.92 & 32.4484 \\
\hline 17 & $\mathrm{CD}$ & 48 & 5 & 25.93 & 28.2761 \\
\hline 18 & $\mathrm{CD}$ & 48 & 10 & 13.41 & 22.5486 \\
\hline
\end{tabular}

$T_{V b}($ biogas yield total mean value $)=26.35 \mathrm{~L} / \mathrm{kg}$

$T_{V b-S / N}($ biogas yield $\mathrm{S} / \mathrm{N}$ ratio total mean value $)=27.4704$

*Data from Sumardiono et al. [14]

were dissolved by $\mathrm{NaOH}$ solution, and then only a less amount of cellulose reacted with $\mathrm{NaOH}$. The suspension of lignin and hemicelluloses could decrease the VS/ TS ratio in bagasse (Table 1). Delignification processes damaged the structure of lignin to make cellulose more accessible to anaerobic bacteria. Based on Table 5 and Fig. 2, increasing the pretreatment time from 0 to $24 \mathrm{~h}$ could enhance the $\mathrm{S} / \mathrm{N}$ ratio from 26.07 to 28.14 . Furthermore, pretreatment during $48 \mathrm{~h}$ resulted in $\mathrm{S} / \mathrm{N}$ of 28.20. It indicates that the longer the pretreatment process, the more the lignin could be removed, which results in high yield.

Table 5. S/N response table for $V b$.

\begin{tabular}{|c|c|c|c|}
\hline \multirow{2}{*}{ Levels } & \multicolumn{3}{|c|}{ Parameters } \\
\cline { 2 - 4 } & $\mathrm{A}$ & $\mathrm{B}$ & $\mathrm{C}$ \\
\hline Level 1 & $\mathbf{2 7 . 5 9}$ & 26.07 & $\mathbf{3 1 . 9 8}$ \\
\hline Level 2 & 27.35 & 28.14 & 27.81 \\
\hline Level 3 & - & $\mathbf{2 8 . 2 0}$ & 22.61 \\
\hline Delta & 0.24 & 2.14 & 9.37 \\
\hline
\end{tabular}

Moreover, the total solid (TS) affected the total biogas volume significantly (Fig. 2). The best TS in this study was $2 \%$. Generally, the optimum range of TS in anaerobic digestion relied upon the substrates. Budiyonoet al. [6] stated that the optimum range of TS was 7-9\% using vinasse as a substrate. Furthermore, Kalia et al. [20] found that TS of 2-4\% was the best in the digestion of banana stem waste. Hence, the results of our study were in line with Kalia et al. [20]. Bagasse and banana stems contained high fibers, but vinasse contained high simple organic compounds. Thus, more water was needed for digesting bagasse and banana stems than digesting vinasse. Consequently, the TS content in digesting bagasse and banana stems was lower than that in digesting vinasse. The substrate contained too high TS and was not good for anaerobic performance. The high TS content caused the high production of volatile fatty acids (VFAs) by acidogenic bacteria activity. Accumulation of VFAs inhibited the methanogenic bacteria growth so that biogas production was low [31, 32-34]. 

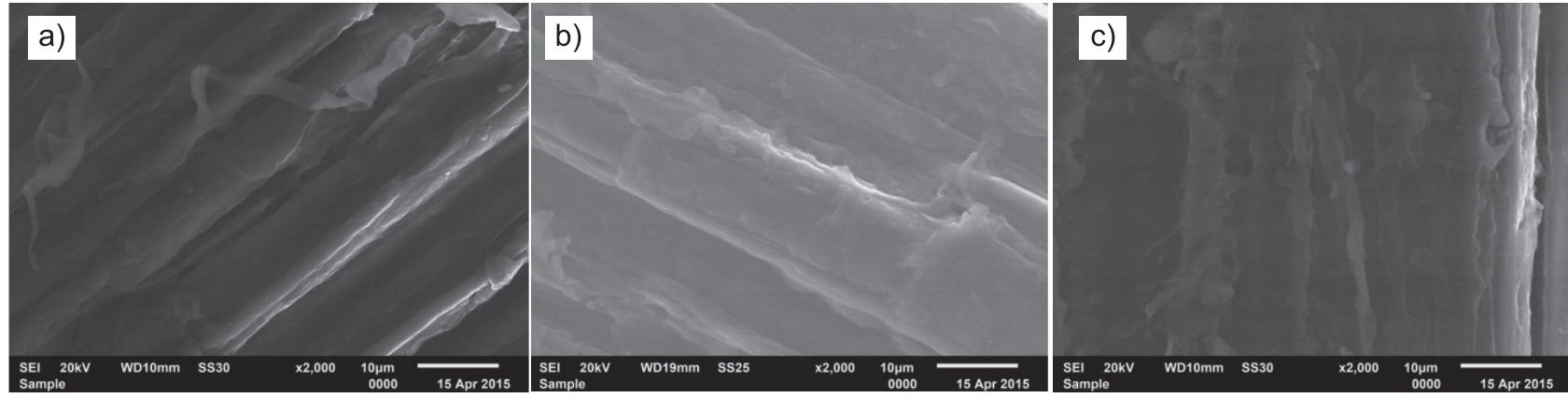

Fig. 3. SEM image of bagasse (magnification 500x), a) before pretreatment, b) after pretreatment during $24 \mathrm{~h}$, c) after pretreatment during $48 \mathrm{~h}[14]$.

\section{Analysis of Variance (ANOVA) Method}

The statistical method of ANOVA was applied to determine the individual interactions of all parameters in the experiments. Therefore, ANOVA was applied to investigate the effects of inoculums type, pretreatment time and total solid on biogas yield. The ANOVA results for biogas yield are shown in Table 6. This analysis was conducted using Minitab software. The significance of parameters in ANOVA was determined by comparing the $\mathrm{F}$ values among the parameters. The parameter $\mathrm{C}$ had the highest $\mathrm{F}$ ratio of all parameters with a value of 61.95. The contribution rate (\%) shows the percentage contribution of each parameter in the process. The more the contribution rate, the more dominant the parameter in the process. According to Table 5, the percentage contribution of parameters $\mathrm{A}, \mathrm{B}$, and $\mathrm{C}$ on the biogas yield is $0.43 \%, 7.97 \%$, and $83.51 \%$ respectively. Thus, the most dominant parameter affecting the biogas yield was total solid (parameter C, 83.51\%). The second dominant parameter was pretreatment (parameter B, $7.97 \%$ ). On the other hand, the inoculums type was the most neglected parameter because of its very low contribution rate (parameter A, $0.43 \%$ ). Furthermore, the percent of error was considered quite low which was $8.09 \%$.

\section{Regression Analysis of Total Biogas}

Correlation between dependent and independent variables could be analyzed and predicted using regressions analysis [25]. In this study, the dependent variable was biogas yield $(V b)$, whereas the independent variables were inoculums $(I n)$, pretreatment time $(T p)$, and total solid (TS). By using linear and quadratic regression models, equations were made to predict the biogas yield and shown in Eq. 2.

$$
\begin{gathered}
V b l(\text { linear })=43.71-1.56 \operatorname{In}+0.1312 T p-3.207 T S \\
\mathrm{R}-\mathrm{Sq}=84.65 \%
\end{gathered}
$$

$\mathrm{Vbl}$ indicates the predicted biogas yield based on the linear regression model. Fig. 4a) shows correlation between the measured and predicted $V b$ based on the experiment and Eq. 2 respectively with correlation coefficient $\mathrm{R}^{2}$ of $84.65 \%$. Furthermore, the equation using quadratic regression model for predicting biogas yield is given in Eq. 3 .

$$
\begin{gathered}
V b q(\text { quadratic })=50.51-2.69 \text { In }+0.694 \\
T p-7.59 T S-0.00791 T p^{2}+0.338 T S^{2} \\
-0.055 \text { InTp }+0.432 \text { InTS }-0.0179 T p T S \\
\mathrm{R}-\mathrm{Sq}=93.43 \%
\end{gathered}
$$

$V b q$ demonstrates the predicted biogas yield based on the quadratic regression model. Fig. 4b) shows correlation between the measured and predicted $V b$ based on the experiment and on Eq. 3 respectively, with correlation coefficient $\mathrm{R}^{2}$ of $93.43 \%$. As a result, the quadratic regression model is proved to be more effective for the estimation of biogas yield.

Table 6. Results of ANOVA for biogas yield.

\begin{tabular}{|c|c|c|c|c|c|}
\hline Variance source & $\begin{array}{c}\text { Degree of freedom } \\
(\text { DoF })\end{array}$ & $\begin{array}{c}\text { Sum of squares } \\
(\text { SS) }\end{array}$ & $\begin{array}{c}\text { Mean of squares } \\
(\mathrm{MS})\end{array}$ & F ratio & Contribution rate (\%) \\
\hline A & 1 & 10.89 & 10.89 & 0.64 & 0.43 \\
\hline B & 2 & 202.00 & 101.00 & 5.91 & 7.97 \\
\hline C & 2 & 2117.37 & 1058.68 & 61.95 & 83.51 \\
\hline Error & 12 & 205.07 & 17.09 & - & 8.09 \\
\hline Total & 17 & 2535.32 & - & - & 100 \\
\hline
\end{tabular}



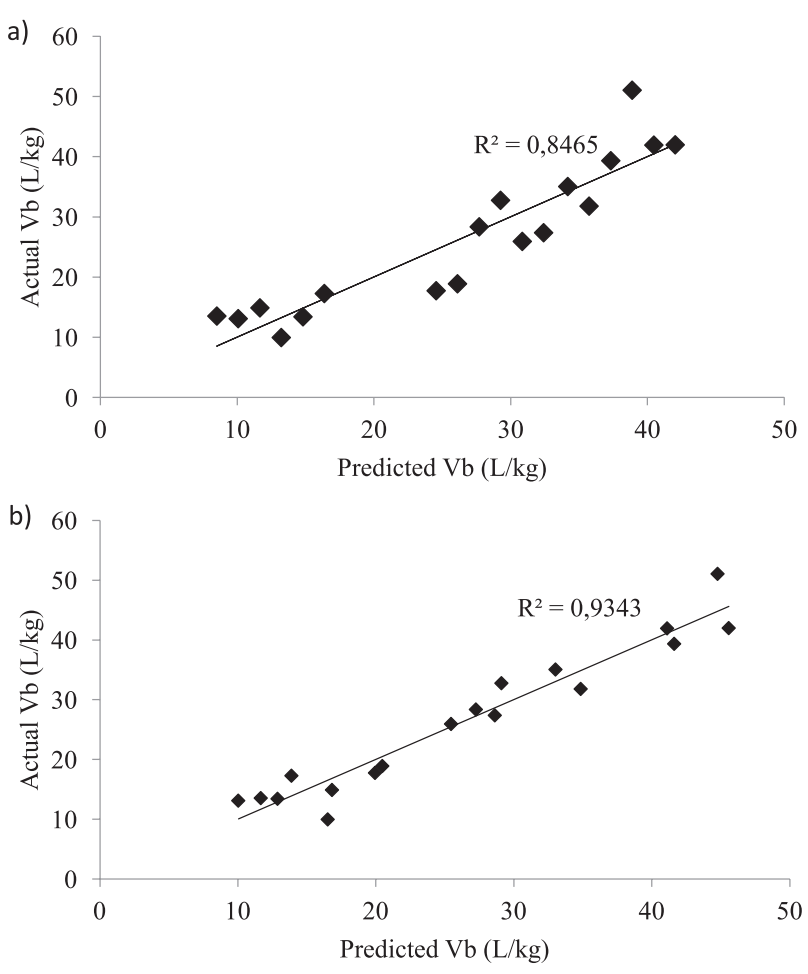

Fig. 4. Comparison of a) the linier regression model and b) quadratic regression model with experimental results for $V b$.

Table 7. Mean response table for $V b$.

\begin{tabular}{|c|c|c|c|}
\hline \multirow{2}{*}{ Levels } & \multicolumn{3}{|c|}{ Parameters } \\
\cline { 2 - 4 } & $\mathrm{A}$ & $\mathrm{B}$ & $\mathrm{C}$ \\
\hline Level 1 & 27.13 & 21.68 & 40.18 \\
\hline Level 2 & 25.57 & 29.39 & 25.17 \\
\hline Level 3 & - & 27.98 & 13.69 \\
\hline Delta & 1.56 & 7.71 & 26.49 \\
\hline
\end{tabular}

\section{Estimation of Maximum Biogas Yield}

By using Taguchi method, a confirmation experiment was conducted for validating the optimization condition [25]. In the estimation of maximum biogas yield, Eq. 4 was used.

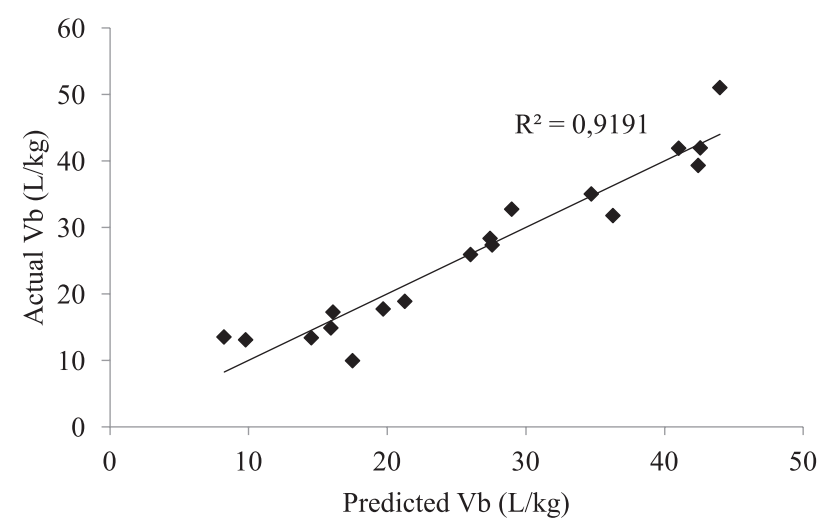

Fig. 5. Comparison of Taguchi model with experimental results for $V b$.

$$
V b_{\max }=\left(\mathrm{A}_{1}-T_{V b}\right)+\left(\mathrm{B}_{3}-T_{V b}\right)+\left(\mathrm{C}_{1}-T_{V b}\right)+T_{V b}(4)
$$

The $\mathrm{A}_{1}, \mathrm{~B}_{3}, \mathrm{C}_{1}$ represented the optimum average values of biogas yield. The value of $V b_{\max }$ was calculated using data of $\mathrm{A}_{1}, \mathrm{~B}_{3}, \mathrm{C}_{1}$ shown in Table 7. Based on the calculations, the maximum biogas yield $\left(\mathrm{Vb}{ }_{\text {max }}\right)$ from the optimum condition was estimated to become $42.59 \mathrm{~L} / \mathrm{kg}$.

\section{Confirmation Test}

Confirmation test about correlation between the parameters and biogas yield was made for the Taguchi method and regression equations (linear and quadratic) at optimum and random levels. In Table 8, the comparison of measured and predicted biogas yield obtained by using the Taguchi method (Eq. 4) and regression equations (Eq. 2-3) are given. The measured and predicted biogas yields are very close to each other. For reliable statistical analyses, error percent must be below 20\% [25]. Therefore, the results obtained from the confirmation tests reflected successful optimization. In addition, Fig. 5 shows the comparison of measured and predicted biogas yield which were obtained by Taguchi model. The comparison resulted in a straight line with good $\mathrm{R}^{2}$ which was $91.9 \%$.

Table 8. Predicted biogas yield and confirmation test results by Taguchi method and regression equations.

\begin{tabular}{|c|c|c|c|c|c|c|c|c|c|}
\hline \multirow{2}{*}{ Level } & \multicolumn{3}{|c|}{ For Taguchi method } & \multicolumn{2}{c|}{ For linier regression equations } & \multicolumn{2}{c|}{ For quadratic regression equations } \\
\cline { 2 - 12 } & $\begin{array}{c}\text { Experiment } \\
(\mathrm{L} / \mathrm{kg})\end{array}$ & $\begin{array}{c}\text { Prediction } \\
(\mathrm{L} / \mathrm{kg})\end{array}$ & $\begin{array}{c}\text { Error } \\
(\%)\end{array}$ & $\begin{array}{c}\text { Experiment } \\
(\mathrm{L} / \mathrm{kg})\end{array}$ & $\begin{array}{c}\text { Prediction } \\
(\mathrm{L} / \mathrm{kg})\end{array}$ & $\begin{array}{c}\text { Error } \\
(\%)\end{array}$ & $\begin{array}{c}\text { Experiment } \\
(\mathrm{L} / \mathrm{kg})\end{array}$ & $\begin{array}{c}\text { Prediction } \\
(\mathrm{L} / \mathrm{kg})\end{array}$ & $\begin{array}{c}\text { Error } \\
(\%)\end{array}$ \\
\hline $\mathrm{A}_{1} \mathrm{~B}_{3} \mathrm{C}_{1}($ Optimum) & 41.97 & 42.59 & 1.48 & 41.97 & 42.03 & 0.14 & 41.97 & 45.58 & 8.60 \\
\hline $\mathrm{A}_{2} \mathrm{~B}_{1} \mathrm{C}_{1}($ Random) & 35.04 & 34.73 & 0.88 & 35.04 & 34.18 & 2.45 & 35.04 & 33.03 & 5.74 \\
\hline $\mathrm{A}_{2} \mathrm{~B}_{2} \mathrm{C}_{2}$ (Random) & 28.35 & 27.43 & 3.25 & 28.35 & 27.70 & 2.29 & 28.35 & 27.26 & 3.84 \\
\hline $\mathrm{A}_{2} \mathrm{~B}_{3} \mathrm{C}_{3}$ (Random) & 13.41 & 14.54 & 8.43 & 13.41 & 14.82 & 10.51 & 13.41 & 12.89 & 3.88 \\
\hline
\end{tabular}




\section{Conclusion}

The Taguchi method was used to determine the optimal parameters in biogas yield from bagasse. Furthermore, the $\mathrm{L}_{18}\left(2^{1} \times 3^{2}\right)$ full factorial design with a mixed orthogonal array was selected to conduct the experiments. The proposed parameters include type of inoculum (cow rumen and cow dung), $\mathrm{NaOH}$ pretreatment time $(0,24,48 \mathrm{~h})$, and total solid $(2,5$, $10 \%$ ). Maximum yield was obtained by adjusting signalto-noise $(\mathrm{S} / \mathrm{N})$ ratio of larger-the-better characteristics. The best level for each parameter was $\mathrm{A}_{1}$ (cow rumen), $\mathrm{B}_{3}(48 \mathrm{~h})$, and $\mathrm{C}_{1}$ (total solid 2\%). This conclusion was based on the $\mathrm{S} / \mathrm{N}$ value in each parameter i.e. 27.59, 28.20, 31.98 for $\mathrm{A}_{1}, \mathrm{~B}_{3}, \mathrm{C}_{1}$ respectively. Cow rumen contained higher ruminant bacteria than cow dung, so bagasse was easier to degrade using the former one. Furthermore, the longer the pretreatment time, the more accessible the cellulose would be by bacteria. Hence resulted in a greater biogas yield. Moreover, too high total solid produce excess in VFAs, which were toxic for biological activity. Hence, the best total solid was $2 \%$. Based on ANOVA, it was found that the total solid was the most dominant parameter on biogas yield with a contribution percentage of $83.51 \%$. Which was followed by pretreatment time (contribution percent of $7.97 \%$ ) and inoculum type (contribution percent of $0.43 \%$ ). Prediction of biogas yield was conducted through developed linear and quadratic regression models which demonstrated a correlation coefficient $\left(\mathrm{R}^{2}\right)$ of 0.846 and 0.934 respectively. Meanwhile, the Taguchi method could predict the biogas yield successfully with $\mathrm{R}^{2}$ of 0.919. According to the confirmation test, The Taguchi method and quadratic regression equation resulted in error prediction below $10 \%$. Hence, it is recommended to apply in the optimization of many parameters for various wastes.

\section{Acknowledgements}

The authors special thank to the Diponegoro University through the World Class Research Universitas Diponegoro (Grant Number 118-19/UN7.6.1/ PP/2021) for supporting this research.

\section{Conflict of Interest}

The authors declare no potential conflict of interest regarding the publication of this work. In addition, the ethical issues including plagiarism, informed consent, misconduct, data fabrication and, or falsification, double publication and, or submission, and redundancy have been completely witnessed by the authors.

\section{References}

1. SYAICHURROZI I., BASYIR M.F., FARRAZ R.M., RUSDI R. A preliminary study: Effect of initial $\mathrm{pH}$ and Saccharomyces cerevisiae addition on biogas production from acid-pretreated Salvinia molesta. Energy, 207, 118226, 2020.

2. SYAICHURROZI I. Biogas production from co-digestion Salvinia molesta and rice strawand kinetics. Renew Energy, 115, 76, 2018.

3. SYAICHURROZI I., RUSDI R., HIDAYAT T., BUSTOMI A. Kinetics Studies Impact of Initial $\mathrm{pH}$ and Addition of Yeast Saccharomyces cerevisiae on Biogas Production from Tofu Wastewater in Indonesia. Int J Eng Transactions B: Applications, 29 (8), 1037, 2016.

4. SYAICHURROZI I., RUSDI, DWICAHYANTO S., TORON Y.S. Biogas Production from Co-Digestion Vinasse Waste and Tofu-Processing Wastewater and Kinetics. Int J Renew Energy Res, 6 (3), 1057, 2016.

5. BUDIYONO, SYAICHURROZI I., SUMARDIONO S. Biogas Production Kinetic from Vinasse Waste in Batch Mode Anaerobic Digestion. World Appl Sci J, 26 (11), 1464, 2013.

6. BUDIYONO, SYAICHURROZI I., SUMARDIONO S. Effect of Total Solid Content to Biogas Production Rate from Vinasse. Int J Eng Transactions B: Applications, 27 (2), 177, 2014.

7. THIRUGNANASAMBANDHAM K. Enhancement of biogas production from wastewater using a batch anaerobic process. Energy Sources, Part A: Recovery, Utilization, and Environmental Effects, 39 (14), 1484, 2017.

8. MARYANA R., MA'RIFATUN D., WHENI A.I., SATRIYO K.W., RIZAL W.A. Alkaline Pretreatment on Sugarcane Bagasse for Bioethanol Production. Energy Procedia, 47, 250, 2014.

9. JANKE L., LEITE A., NIKOLAUSZ M., SCHMIDT T., LIEBETRAU J., NELlES M., STINNER W. Biogas Production from Sugarcane Waste: Assessment on Kinetic Challenges for Process Designing. Int J Mol Sci, 16, 20685, 2015.

10. VRIEZE J.D., RAPORT L., WILLEMS B., VERBRUGGE S., VOLCKE E., MEERS E., ANGENENT L.T., BOON $\mathrm{N}$. Inoculum selection influences the biochemical methane potential of agro-industrial substrates. Microb Biotechnol 8, 776, 2015.

11. TALHA Z., DING W., MEHRYAR E., HASSAN M., BI J. Alkaline Pretreatment of Sugarcane Bagasse and Filter Mud Codigested to Improve Biomethane Production. BioMed Res Int, 2016, 1, 2016.

12. SIMO W.S.F., JONG E.N., KAPSEU C. Improving Biogas Production of Sugarcane Bagasse by Hydrothermal Pretreatment. Chem Biomol Eng, 1 (3), 21, 2016.

13. KEERTHANA T., KRISHNAVENI A. Biogas production from sugarcane bagasse in co-digestion with vegetable waste. Int J Latest Eng Res Appl, 1 (3), 113, 2016.

14. SUMARDIONO S., RIYANTA A.B., MATIN H.H.A., KUSWORO T.D., JOS B., BUDIYONO. Increasing biogas production from sugar cane baggase by anaerobic co-digestion with animal manure. MATEC Web of Conferences, 101, 02014, 2017.

15. DEEPANRAJ B., SIVASUBRAMANIAN V., JAYARAJ S. Multi-response optimization of process parameters in biogas production from food waste using Taguchi-Grey relational analysis. Energy Convers Manage, 141, 429, 2017. 
16. MEHRYAR E., DING W., HEMMAT A., HASSAN M., TALHA Z., KAFASHAN J., HUANG H. Modeling and Multiresponse Optimization for Anaerobic Codigestion of Oil Refinery Wastewater and Chicken Manure by Using Artificial Neural Network and the Taguchi Method. BioMed Res Int, 1, 2017.

17. SYAICHURROZI I., VILLTA P.K., NABILAH N., RUSDI R. Effect of sulfuric acid pretreatment on biogas production from Salvinia Molesta. J Environ Chem Eng, 7, 102857, 2019.

18. YAVINI T.D., CHIA A.I., JOHN A. Evaluation of the Effect of Total Solids Concentration on Biogas Yields of Agricultural Wastes. Int Res J Environ Sci, 3 (2), 70, 2014.

19. IGONI A.H., ABOWEI M.F.N., AYOTAMUNO M.J., EZE C.L. Effect of Total Solids Concentration of Municipal Solid Waste on the Biogas produced in an Anaerobic Continuous Digester. Agric Eng Int, 10, 1, 2008.

20. KALIA V.C., SONAKYA V., RAIZADA N. Anaerobic digestion of banana stem waste. Bioresour Technol, 73, 191, 2000.

21. SYAICHURROZI I., BUDIYONO, SUMARDIONO S. Predicting kinetic model of biogas production and biodegradability organic materials: Biogas production from vinasse at variation of $\mathrm{COD} / \mathrm{N}$ ratio. Bioresour Technol, 149, 390, 2013.

22. MA S., WANG H., WANG Y., BU H., BAI J. Bio-hydrogen production from cornstalk wastes by orthogonal design method. Renew Energy, 36, 709-713, 2011.

23. KARABAS H. Biodiesel production from crude acorn (Quercus frainetto L.) kernel oil: An optimisation process using the Taguchi method. Renew Energy, 53, 384, 2013.

24. DHAWANE S.H., KUMAR T., HALDER G. Biodiesel synthesis from Heveabrasiliensis oil employing carbon supported heterogeneous catalyst: Optimization by Taguchi method. Renew Energy, 89, 506, 2016.

25. KIVAK T. Optimization of surface roughness and flank wear using the Taguchi method in milling of Hadfield steel with PVD and CVD coated inserts. Measurement, 50, 19, 2014.

26. DADASER-CELIK F., AZGIN S.T., YILDIZ Y.S. Optimization of solid content, carbon/nitrogen ratio and food/inoculum ratio for biogas production from food waste. Waste Manag Res, 34 (12), 1241, 2016.

27. PERTIWININGRUM A., SUSILOWATI E., ROCHIJAN, FITRIYANTO N.A., SOEHERMAN Y., HABIBI M.F. Potential Test on Utilization of Cow's Rumen Fluid to Increase Biogas Production Rate and Methane Concentration in Biogas. Asian J Anim Sci, 11 (2), 82, 2017.

28. BUDIYONO, WIDIASA I.N., JOHARI S., SUNARSO. The Influence of Total Solid Contents on Biogas Yield from Cattle Manure Using Rumen Fluid Inoculum. Energy Res J, 1 (1), 6, 2010.

29. KONG F., ENGLER C., SOLTES E. Effects of cellwall acetate, xylan backbone and lignin on enzymatic hydrolysis of aspen wood. Appl Biochem Biotech, 34 (1), 23, 1992.

30. MONTGOMERY L.F.R., BOCHMANN G. Pretreatment of feedstock for enhanced biogas production, IEA Bioenergy, British Library, 2014. https://books.google. co.id/books/about/Pretreatment_of_Feedstock_for Enhanced_B.html?id=KL5TrgEACAAJ\&redir_esc $=\bar{y}$ (accessed on 14 June 2020).

31. JUNTARASIRI; NIJSUNKIJ P.S., BUATICK T., JAMKRAJANG E., WACHARAWICHANANT S., SEADAN M., WASANTAKORN A., SUTTIRUENGWONG S. Enhancing Biogas Production from Padauk Angsana Leave and Wastewater Feedstock through Alkaline and Enzyme Pretreatment. Energy Procedia, 9, 207, 2011.

32. CARNEIRO T.F., PEREZ M., ROMERO L.I. Influence of total solid and inoculum contents on performance of anaerobic reactors treating food waste. Bioresour Technol, 99, 6994, 2008.

33. JHA A.K., LI J., ZHANG L., BAN Q., JIN Y. Comparison between wet and dry anaerobic digestions of cow dung under mesophilic and thermophilic condition. Adv Water Resour Protec, 1 (2), 28, 2013.

34. LI. Y., ZHU J., WAN C., PARK S.Y. Solid-State anaerobic digestion of corn stover for biogas production. Am Soc Agric Biol Eng, 54 (4), 1415, 2011. 